\title{
Photoactivation and photoregeneration of Ti02/PAC mixture applied in suspension in water treatments: approach to a real application
}

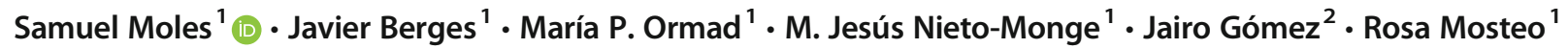 \\ Received: 2 July 2020 / Accepted: 14 January 2021 \\ (C) The Author(s), under exclusive licence to Springer-Verlag GmbH, DE part of Springer Nature 2021
}

\begin{abstract}
The process $\mathrm{TiO}_{2} / \mathrm{PAC} / \mathrm{UV}$-vis has been under study and compared with the isolated treatments of adsorption and photocatalysis determining possible synergies between adsorption and photocatalysis of target antibiotics: amoxicillin, enrofloxacin, sulfadiazine, and trimethoprim. The characterization of the TiO2/PAC mixture was carried out via FESEM and FTIR. Moreover, a kinetic study has been performed. The effect of UV-vis radiation and the type of matrix was analyzed in $\mathrm{TiO}_{2} / \mathrm{PAC} / \mathrm{UV}$-vis process. The performance of this treatment has been monitored during three cycles, evaluating also the regeneration of TiO $/ 2 / \mathrm{PAC}$ mixture by UV-vis light. $\mathrm{TiO}_{2} / \mathrm{PAC} / \mathrm{UV}$-vis process allowed the removal of the antibiotics in the range 90-100\% (an average removal of $93 \%$ of the initial concentration) after $60 \mathrm{~min}$ of treatment. However, only amoxicillin showed a significant synergy applying $\mathrm{TiO}_{2} / \mathrm{PAC} / \mathrm{UV}$-vis process. Regarding matrix effect, no influence of the matrix type (ultrapure water or treated wastewater) was observed. Since PAC tends to be deactivated gradually, the $\mathrm{TiO}_{2} / \mathrm{PAC} / \mathrm{UV}$-vis process performance decreases after each cycle in a $15 \%$ average. Finally, regeneration via UV-vis light started to be effective after a total of $4 \mathrm{~h}$ of regeneration.
\end{abstract}

Keywords $\mathrm{TIO}_{2}$-UV/vis photocatalysis $\cdot$ Antibiotic $\cdot$ Powered activated carbon (PAC)

\section{Introduction}

Antibiotics have shown an incipient use to fight a variety of diseases, leading to a rise of its global consumption.

\section{Responsible Editor: Sami Rtimi}

Highlights
- The application of $\mathrm{TiO} 2 / \mathrm{PAC} / \mathrm{UV}$-vis in suspension is a promising
process, because it is environmentally friendly reducing energy and
chemicals. This process allows effectively the removal of target
antibiotics.
- There is no influence of the matrix type (ultrapure water or treated
wastewater) in $\mathrm{TIO}_{2} / \mathrm{PAC} / \mathrm{UV}$-vis process applied in suspension.
- The $\mathrm{TiO}_{2} / \mathrm{PAC}$ mixture tends to be deactivated among various cycles.
According to the results, an average of $15 \%$ removal is reduced for the
target antibiotics per cycle. Nevertheless, the regeneration of PAC is
possible by applying, at least, 4 h of exposure to $3 \mathrm{~W} / 1$ of $\mathrm{UV}$-vis light,
allowing its reuse.

\section{Samuel Moles}

sma@unizar.es

1 Research Group Agua y Salud Ambiental, University of Zaragoza, Zaragoza, Spain

2 Navarra de Infraestructuras Locales SA, Pamplona, Spain
Nowadays, antibiotics are mainly destined to human and veterinary uses, thus creating a waste problem, as more than a half of the antimicrobial agent given is excreted (Klein et al., 2018; Kuehn, 2007). It is widely believed that massive and improper use of these pharmaceuticals might cause a serious problem on environment (Mceneff et al., 2014). Since the consumption of antibiotics leads to the subsequent generation of antimicrobial-resistant bacteria (AMR), apart from the environment, public health is also involved in the negative effects caused by the current use of antibiotics.

Urban wastewater treatment plants (WWTP), which receive the antibiotics and metabolites excreted, as well as other pollutants, are not designed to remove antibiotics. Although they reduce some of them (Mceneff et al., 2014), many studies have monitored the occurrence of the most commonly administered pharmaceuticals in urban wastewater, groundwater, and surface water worldwide. The literature informs that concentrations of antibiotics from ng/l to $\mu \mathrm{g} / \mathrm{l}$ are detected in waters (García-Galán et al., 2010; Jurado et al., 2019; BoyRoura et al., 2018; García-Gil et al., 2018). Among the different families of antibiotics, sulfonamides (Senta et al., 2013; Babić et al., 2006), trimethoprim (Golovko et al., 2014; Aukidy et al., 2012), $\beta$-lactams (Tuc Dinh et al., 2011; 
Rossmann et al., 2014), and fluoroquinolones (Tamtam et al., 2008; Wagil et al., 2014) represent a potential risk for the environment. Consequently, a representative antibiotic from each one of these groups was analyzed in this research work, more precisely: sulfadiazine (veterinary use, sulfonamide), trimethoprim (human and veterinary use, trimethoprim), amoxicillin (human and veterinary use, $\beta$-lactam), and enrofloxacin (veterinary use, fluoroquinolone).

Conventional treatments, such as coagulation-flocculationdecantation or biologic processes, are not able to completely remove these pollutants. However, other type of treatments has been studied in the last decade to remove emerging pollutants. Photocatalysis and adsorption have been demonstrated to be effective for pharmaceuticals removal (USEPA, 2007; Mirzaei et al., 2017; Biancullo et al., 2019; Cai \& Hu, 2017). An alternative approach to remove antibiotics from water could be the combination of the adsorbent activated carbon (AC) and the catalyst $\mathrm{TiO}_{2}$. The immobilized system based on porous adsorbents, such as carbon fibers or zeolites, is quite common for carbonaceous-TiO2 composites. Activated carbon (AC), carbon nanotubes or carbon fibers, and graphene are mainly applied to synthetize carbonaceous$\mathrm{TiO}_{2}$ composites, for instance, by means of thermal treatments which induces to high-energy consumption. Many methods have been developed for preparing carbonaceous-TiO2 composites. These systems have been widely investigated and are promising materials for future high-activity photocatalysts for pharmaceuticals such as amoxicillin (Moura et al., 2018; Awfa et al., 2018). The presence of the carbonaceous material may facilitate enhanced photocatalytic activity through one or all of the three primary mechanisms: (i) band-gap tuning or extension of excitation wavelength through photosensitization, (ii) retardation of electron-hole recombination, and (iii) provision of high-surface area for adsorption of reactants and provision of active sites. The carbonaceous- $\mathrm{TiO}_{2}$ photocatalysts have the potential to address all three aspects. Moreover, they are widely reported to enhance photocatalytic activity over that of $\mathrm{TiO}_{2}$ alone. However, many of them require many chemicals and are expensive, complicated, and time-consuming. Therefore, the development of relatively cheap, easy, scalable, and environmentally friendly method is a one of the very high priorities according to literature (Awfa et al., 2018).

However, though immobilized systems such as the aforementioned carbonaceous- $\mathrm{TiO}_{2}$ composites are the most common way to combine carbon and $\mathrm{TiO}_{2}$, more options are reported in literature to achieve this combination (Awfa et al., 2018; Moles et al., 2020; Andriantsiferana et al., 2014; Matos et al., 1998). The general trend nowadays consists on the immobilization of the catalyst in the surface or the adsorbent (Andriantsiferana et al., 2014). Nevertheless, in this research, work is considered the application of powered activated carbon (PAC) and $\mathrm{TiO} 2$ in suspension resulting in an amalgam of them. The application of $\mathrm{TiO} 2 / \mathrm{PAC}$ mixture in suspension allows a better contact surface between the pollutants and the mixture and previous results in our research group show that separation processes based on coagulation-flocculationdecantation work very well (Moles et al., 2020). This alternative has been applied for the removal of emerging pollutants from waters, such as azo-dye (Andriantsiferana et al., 2014), phenol (Matos et al., 1998), or 4-clorophenol (Herrmann et al., 1999), reporting a synergistic effect. This effect was observed not only in the photocatalysis but also in the adsorption (Herrmann et al., 1999; Bahrudin \& Nawi, 2018). Some authors have pointed that this synergy does not really takes place, and it comes from a misinterpretation of the Langmuir-Hinshelwood equation (Asenjo et al., 2013). Some previous studies can be found coupling two metal oxides (Qiu et al., 2012), or combining metal oxides and MOFs, reporting a synergetic effect in the removal of sulfamethazine (Yu et al., 2019), methylene blue (Mills, 2012), and bacterial inactivation (Milosevic et al., 2017). However, there is not literature about the removal of antibiotics applying $\mathrm{TiO}_{2} /$ PAC mixture in suspension combined with UV-vis light $\left(\mathrm{TiO}_{2} / \mathrm{PAC} / \mathrm{UV}\right.$-vis$)$. Consequently, there is a need to determine the possible synergy of these materials in water treatments.

This work evaluates the capacity of $\mathrm{PAC} / \mathrm{TiO}_{2} / \mathrm{UV}$-vis process applied in suspension in the removal of antibiotics. The TiO2/PAC mixture was characterized via FTIR and FESEM. Moreover, the kinetic mechanism was proposed for the removal of antibiotics. The performance of this treatment has been monitored during three cycles. Finally, this research work has evaluated the effect of the $\mathrm{TiO}_{2} / \mathrm{PAC}$ mixture regeneration applying UV-vis light. Furthermore, a comparison with the isolated processes (PAC adsorption and $\mathrm{TiO}_{2}$ photocatalysis) is featured to determine possible synergies of $\mathrm{PAC} / \mathrm{TiO} 2 / \mathrm{UV}$-vis in the removal of target antibiotics. The effect of the matrix and UV-vis radiation per unity of volume has been investigated as well.

\section{Materials and methods}

\section{Antibiotic characterization}

The four target antibiotics were supplied by Sigma-Aldrich. Their characteristics are shown in Table 1 including the molecular structure and physicochemical properties of the molecules.

Antibiotic concentration was quantified by UV-vis absorption molecular spectrometry, using a Helios ThermoSpectronic and a quartz cell with a $1.0 \mathrm{~cm}$ path and repeating the absorbance measure of the solution by triplicate. The samples were filtrated with GVS $0.45 \mu \mathrm{m}$ nylon filters previously to the analysis. The characteristic wavelength for sulfadiazine was 254 
Characteristics of the antibiotics selected: name, group, CAS number, molecular weight, acid dissociation constant, and molecular structure

\begin{tabular}{|c|c|c|c|c|c|}
\hline Antibiotics & Group & CAS & $\mathrm{pKa}$ & $\mathrm{MW}$ & Structure \\
\hline Amoxicillin & $\beta$-lactam & $26787-78-0$ & 3.2 (carboxyl) & 365.4 & \\
\hline Enrofloxacin & Fluoroquinolone & $93106-60-6$ & 6.2 & 359.4 & \\
\hline Sulfadiazine & Sulfonamide & $68-35-9$ & 6.4 & 250.3 & \\
\hline Trimethoprim & Trimethoprim & $738-70-5$ & 7.1 & 290.3 & \\
& & & & & \\
\hline
\end{tabular}

$\mathrm{nm}, 202 \mathrm{~nm}$ for trimethoprim, $225 \mathrm{~nm}$ for amoxicillin, and $271 \mathrm{~nm}$ for enrofloxacin. Calibration curves were made using solutions of each antibiotic in deionized water in a range of $1-$ $20 \mathrm{mg} / \mathrm{l}$. The calibration curves for all the antibiotics showed a high linearity $(r>0.99)$. Therefore, concentrations as low as 1 $\mathrm{mg} / \mathrm{l}$ could be reliably measured under these conditions.

\section{Adsorbent characterization}

VPlus vegetal powdered activated carbon (PAC) supplied by Chemivall was used as the adsorbent. According to the specifications given by the manufacturer, the particle size of $90 \%$ of the constituent particles was under $0.044 \mu \mathrm{m}$. Further specifications given are $10.3 \%$ humidity when packaging, $1.8 \%$ ashes on dry basis, as well as an iodine index of $950 \mathrm{mg} / \mathrm{g}$.

Partial elemental analysis was also carried out, obtaining the carbon $(95.8 \%)$, hydrogen $(0.1 \%)$, and nitrogen $(0.2 \%)$ contents. A scanning electron microscope (SEM) study complemented this information with other relevant elements such as oxygen $(2.9 \%)$, aluminum $(0.4 \%)$, silicon $(0.7 \%)$, and iron $(0.2 \%)$. In addition, a BET isotherm was performed, using a Chemisorb 2700 (micrometrics Instruments), measuring the flux of $\mathrm{N}_{2}$ at a temperature of $77 \mathrm{~K}$, yielding a superficial area of $745.4 \mathrm{~m}^{2} / \mathrm{g}$.

\section{Catalyst characterization}

In this study, $\mathrm{TiO}_{2} \mathrm{FN} 2$ was used (aqueous suspension) commercialized by Levenger. Crystalline phases were analyzed by X-Ray Diffraction (XRD) with a diffractometer Rigaku $\mathrm{D} / \mathrm{Max}-2500$, provided with a graphite monochromator to select the $\mathrm{Cu} \mathrm{K} \alpha$ radiation. Measure interval $(2 \theta)$ went from 10 to $80^{\circ}$ at a speed of $1.8^{\circ} / \mathrm{min}$. Determination and quantification of phases and size particle calculus were carried out with the software MDI-Jade7 and the data base JCPDSInternational Centre for Diffraction Data-2000. For the semi-quantitative analysis of X-Ray fluorescence (XRF), a sequential XRF spectrophotometer Thermo Electron ARL ADVANT'XP was used. This XRF equipment was provided with an X-Ray tube with frontal window of beryllium $(\mathrm{Be})$ and a rhodium $(\mathrm{Rh})$ anode and it permitted the semi-quantitative detection of the elements between sodium $(\mathrm{Na})$ and uranium $(\mathrm{U})$. Particle morphology was studied by field emission scanning electron microscopy (FESEM) with a FESEM microscope Carl Zeiss MERLIN ${ }^{\mathrm{TM}}$ containing a secondary and retro-dispersed electrons detector.

Figure $\mathrm{S} 1$ presents the XRD patterns of $\mathrm{TiO}_{2}$ Levenger. The peaks observed in the diffractogram showed crystalline structures of gypsum $\mathrm{CaSO}_{4} \cdot \mathrm{H} 2 \mathrm{O}(8 \%)$ and smithsonite $\mathrm{ZnCO}_{3}(4 \%)$, along with the phases of $\mathrm{TiO}_{2}$, anatase (79\%), and rutile $(9 \%)$.

The results obtained by XRD were confirmed by the semiquantitative elemental analysis of X-ray fluorescence. Average particle size was calculated from the XRD data, resulting in $23 \mathrm{~nm}$ for $\mathrm{TiO}_{2}$ Levenger. Figure S2 shows a FESEM image of the catalyst. $\mathrm{TiO}_{2}$ Levenger features the presence of bigger size (> $300 \mathrm{~nm}$ ) particles with straight edges was also detected. Probably, these particles correspond to the CaSO4.H2O identified by XRD and XRF. TSS in $\mathrm{TiO}_{2}$ Levenger was $106 \mathrm{~g} / \mathrm{l}$, which means a concentration of around $93 \mathrm{~g} / 1 \mathrm{TiO}_{2}$. 
Fig. 1 FTIR-NIR of the mixture TiO2/PAC entre $400-12800 \mathrm{~cm}^{-1}$

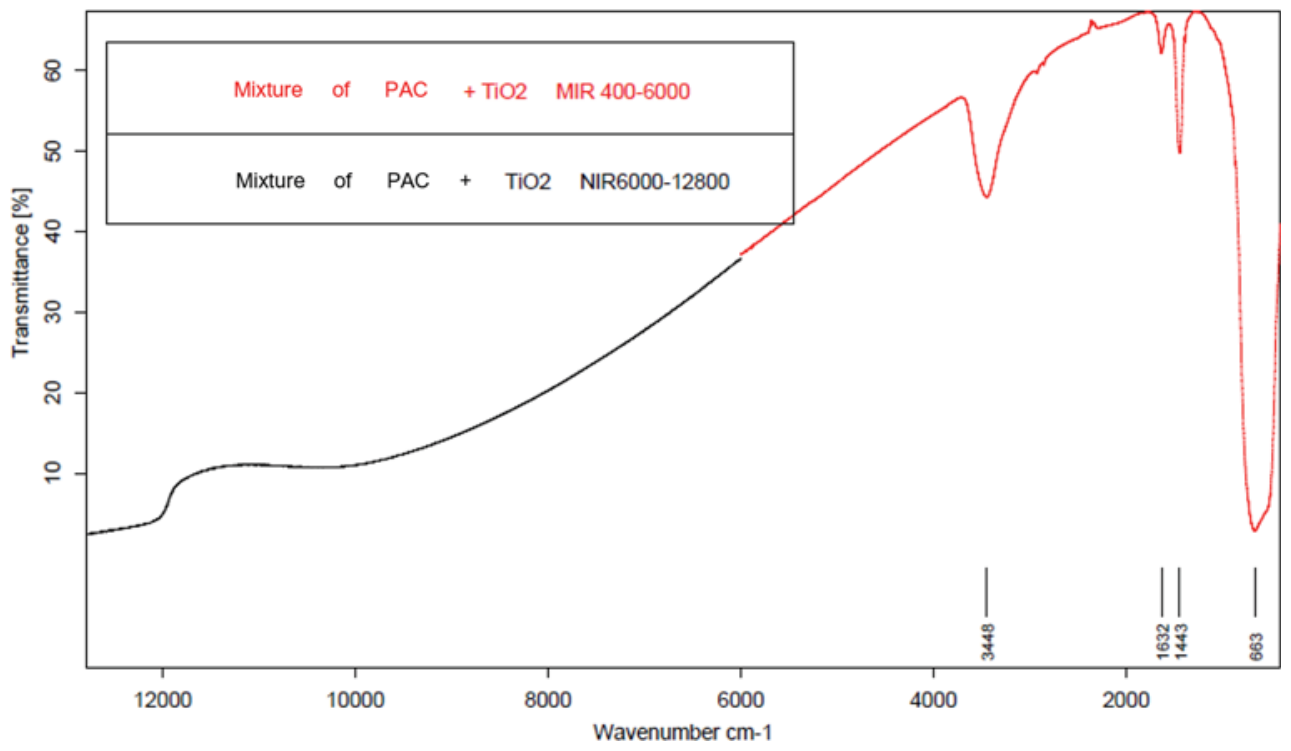

\section{Ti02/PAC mixture characterization}

The TiO2/PAC mixture was characterized via FTIR spectroscopy before and after the adsorption of amoxicillin in a Bruker Vertex 70 spectrometer. The measurement of the samples was carried out in a $\mathrm{KBr}$ disk. The acquisition range of the characterization was $400-12800 \mathrm{~cm}^{-1}$, the resolution was $4 \mathrm{~cm}^{-1}$, and the number of cumulative spectra was 32 .

The characterization of the solid TiO2/PAC is shown in Fig. 1. According to the graph, the main functional groups of the $\mathrm{TiO} 2 / \mathrm{PAC}$ mixture present vibrations at 633,1443 , 1632 , and $3448 \mathrm{~cm}^{-1}$, which usually appear in $\mathrm{TiO} 2$ according to literature (León et al., 2017; Maletić et al., 2019; Al-Amin et al., 2016). The $3448 \mathrm{~cm}^{-1}$ corresponds to the stretching of $\mathrm{O}-\mathrm{H}$ bonds formed between the hydrogen atoms present in PAC or the water molecules entrapped and the oxygen atoms of $\mathrm{TiO} 2$, and the $1632 \mathrm{~cm}^{-1}$ corresponds to the bending of an $\mathrm{O}-\mathrm{H}$ bond associated to a Ti atom. The peak in $1443 \mathrm{~cm}^{-1}$ could be related to the Ti-O bond, as well as the peak present in $663 \mathrm{~cm}^{-1}$. In the NIR, a composed peak is observed around $12000 \mathrm{~cm}^{-1}$ that could be associated with the "band gap" of the mixture. The findings would confirm the formation of $\mathrm{TiO} 2$ nanoparticles.

To complement the characterization of the TiO2/PAC mixture, particle morphology was studied by field emission scanning electron microscopy (FESEM) with a FESEM microscope Carl Zeiss MERLINTM containing a secondary and retro-dispersed electrons detector.

FESEM results are shown in Fig 2. According to the graphs, it can be observed that activated carbon has a porous and smooth surface of the order of 5-10 $\mu \mathrm{m}$, while $\mathrm{TiO} 2$ is agglomerated in round particles $(300-1500 \mathrm{~nm})$. Electron backscatter diffraction allows the determination of the particles and the lightest ones. In this case, titanium oxide particles are the heaviest ones (white) while PAC is observed in black. Figures $2 \mathrm{c}$ and $2 \mathrm{~d}$ (zoom of the graph) suggest that $\mathrm{TiO} 2$ is adsorbed covering the small pores and surface of the PAC. Since PAC has an affinity for antibiotics, the application of the catalyst and the adsorbent simultaneously could have a capacity to generate synergy and increase the performance of the process, as occurs in other treatments in which the carbonaceous material is impregnated with titanium dioxide

\section{Experimental procedure}

The experiments were performed in ultrapure water $(\mathrm{pH} 6.5)$ and in a real-treated urban wastewater (WWTP of 80,000 inhabitants located in the Ebro Basin) fortified with $15 \mathrm{mg} / \mathrm{l}$ of the selected antibiotics individually.

PAC adsorption experiments were conducted in presence of PAC Vplus (supply by ChiemiVall) concentration of $0.1 \mathrm{~g} / 1$ in the dark in $200 \mathrm{ml}$ of sample with a stirring of $150 \mathrm{rpm}$.

Atlas Suntest CPS+ solar chamber provided with a xenon lamp was used for the photo-treatments. For the $\mathrm{TiO}_{2} / \mathrm{UV}$-vis experiments, the samples were exposed to a light intensity of $540 \mathrm{~W} / \mathrm{m}^{2}$ and temperature of $35{ }^{\circ} \mathrm{C}$ in presence of $1 \mathrm{~g} / \mathrm{l}$ of $\mathrm{TiO}_{2}$ FN2. The essays were carried out with $200 \mathrm{ml}$ of sample in sterile $250 \mathrm{ml}$ quartz beakers with continuous stirring of $150 \mathrm{rpm}$. $\mathrm{TiO}_{2} / \mathrm{PAC} / \mathrm{UV}$-vis experiments were carried out in the aforementioned solar chamber applying a dose of $0.1 \mathrm{~g} / \mathrm{l}$ of PAC and $1 \mathrm{~g} / \mathrm{l}$ of $\mathrm{TiO}_{2}$. The samples were exposed to different light intensities per volume unit (Iv) ranging from 1 to $3 \mathrm{~W} / \mathrm{l}$. The rest of the parameters remain constant for each tested antibiotic. 

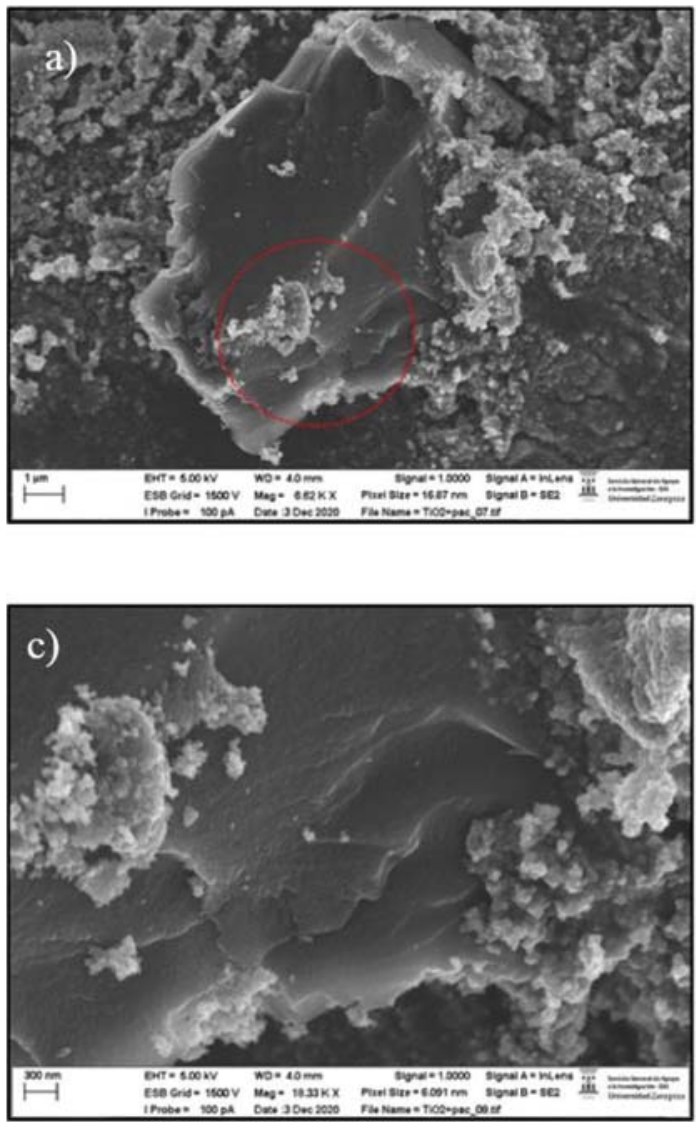
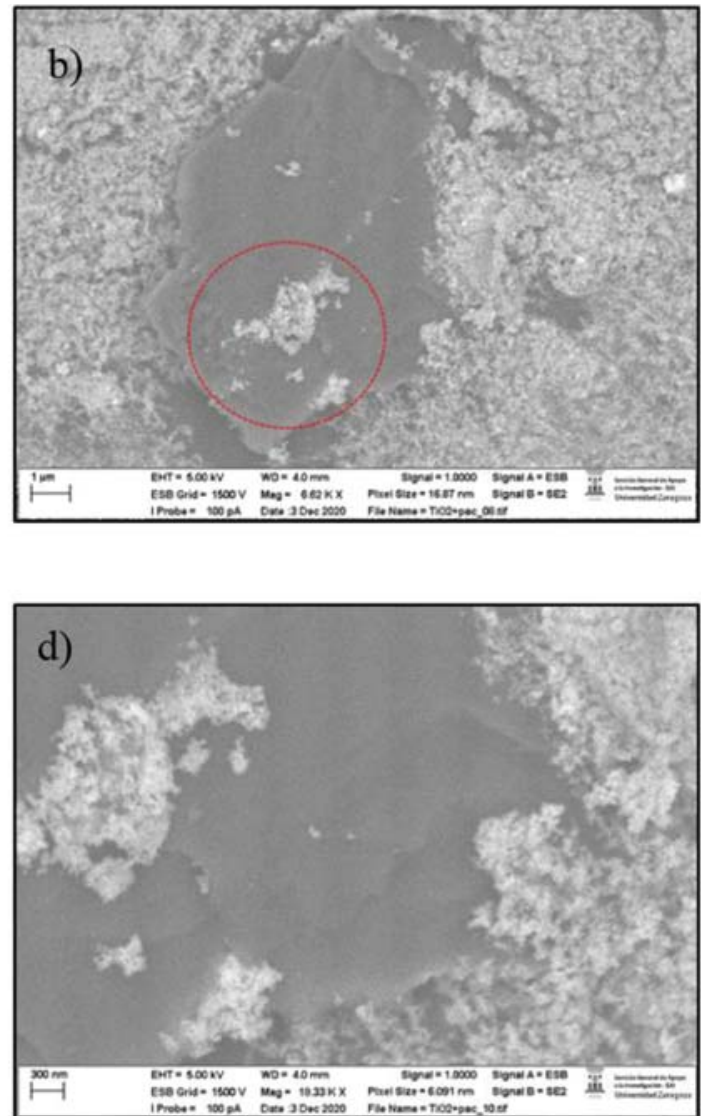

Fig. 2 FESEM of the mixture TiO2/PAC. Electron dispersive spectroscopy (a, c). Electron backscatter diffraction (b, d)

The three tested processes were conducted for treatment times of 10, 30, and $60 \mathrm{~min}$. The antibiotic removal rate from the solution was calculated following Eq. 1:

$\%$ Removal $=\frac{C_{0}-C_{f}}{C_{0}} 100$

\section{Reuse experiments in $\mathrm{PAC} / \mathrm{TiO}{ }_{2} / \mathrm{UV}$-vis process}

Reuse experiments were performed in ultrapure water fortified individually with $15 \mathrm{mg} / \mathrm{l}$ of the four target antibiotics, applying a suspension of $0.1 \mathrm{~g} / 1$ of PAC and $1 \mathrm{~g} / 1$ of $\mathrm{TiO}_{2}$, as well as a radiation per volume unit of $1 \mathrm{~W} / 1$. These experiments consist of three consecutive cycles of $60 \mathrm{~min}$. The mixture was filtered with a nylon filter, manufactured by GVS $(0.45 \mu \mathrm{m}$ pore size). Between each cycle, the $\mathrm{TiO}_{2} / \mathrm{PAC}$ mixture was dried in a stove at $105^{\circ} \mathrm{C}$ for $30 \mathrm{~min}$ and was weighed before and after the drying in order to quantify mass losses between cycles.

\section{Regeneration experiments in $\mathrm{PAC} / \mathrm{TiO} \mathrm{O}_{2} / \mathrm{UV}$-vis process}

Regeneration essays were performed applying a radiation per volume (Iv = $1 \mathrm{~W} / \mathrm{l})$ in ultrapure water fortified with $15 \mathrm{mg} / \mathrm{l}$ of sulfadiazine. The experiment was composed of three cycles with a maximum treatment time of $60 \mathrm{~min}$. The control parameter (molecular absorbance) was measured at 30 and $60 \mathrm{~min}$ in presence of $1 \mathrm{~g} / 1$ of $\mathrm{TiO}_{2}$ and $0.1 \mathrm{~g} / 1$ of PAC. The $\mathrm{TiO}_{2} / \mathrm{PAC}$ mixture was recovery from the solution by mean of $0.45 \mu \mathrm{m}$ nylon filters. The regeneration procedure consists of two steps; first, dried in a stove at $105{ }^{\circ} \mathrm{C}$ for $15 \mathrm{~min}$ to determine mass losses. Immediately after, the dried catalyst was rinsed with $200 \mathrm{ml}$ of water and was placed in a flask and mixed in the solar chamber for $2 \mathrm{~h}$ at $\mathrm{Iv}=3 \mathrm{~W} / \mathrm{l}$.

\section{Results and discussion}

\section{Performance comparison of the three treatments}

In Fig. 3, the $\mathrm{TiO}_{2} / \mathrm{PAC} / \mathrm{UV}$-vis results are reflected, the individual treatments ( $\mathrm{PAC}$ adsorption and $\mathrm{TiO}_{2} / \mathrm{UV}$-vis), and the results of the application of both treatments as sequential steps $\left(\mathrm{TiO}_{2} / \mathrm{UV}\right.$-vis process followed by PAC adsorption). The results suggest that higher removal of amoxicillin, enrofloxacin, and sulfadiazine was found in the $\mathrm{TiO}_{2} / \mathrm{PAC} / \mathrm{UV}$-vis treatment compared to the individual PAC adsorption and $\mathrm{TIO}_{2} /$ UV-vis oxidation. By contrast, trimethoprim removal degree was similar in the isolated treatments and in the $\mathrm{TiO}_{2} / \mathrm{PAC} /$ 
Fig. 3 Evolution of antibiotic removal degree applying different treatment $\mathbf{a}$ amoxicillin, $\mathbf{b}$ enrofloxacin, $\mathbf{c}$ sulfadiazine, $\mathbf{d}$ trimethoprim. $C_{0}=15 \mathrm{mg} / \mathrm{l}, \mathrm{Iv}=1$ $\mathrm{W} / 1,1 \mathrm{~g} / 1 \mathrm{TiO}_{2}, 0.1 \mathrm{~g} / 1 \mathrm{PAC}$

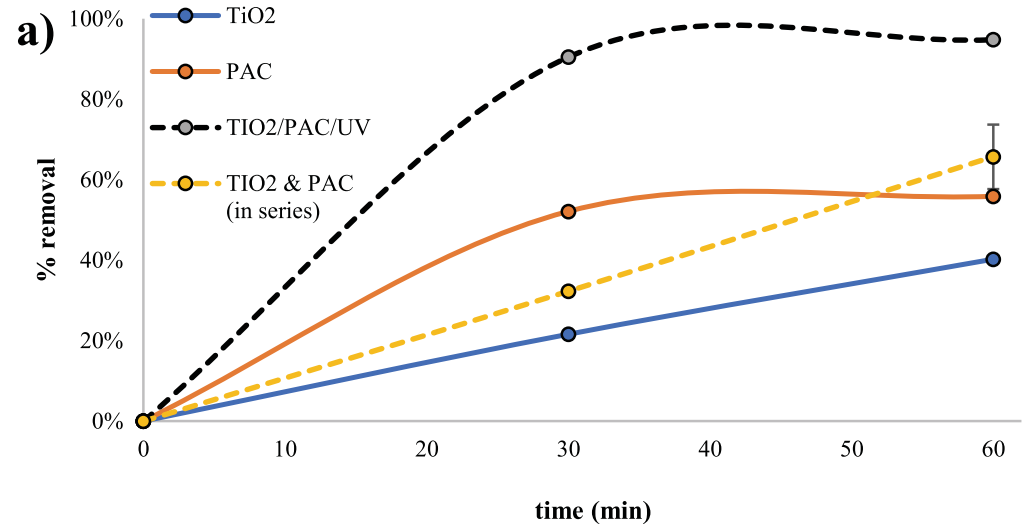

b)
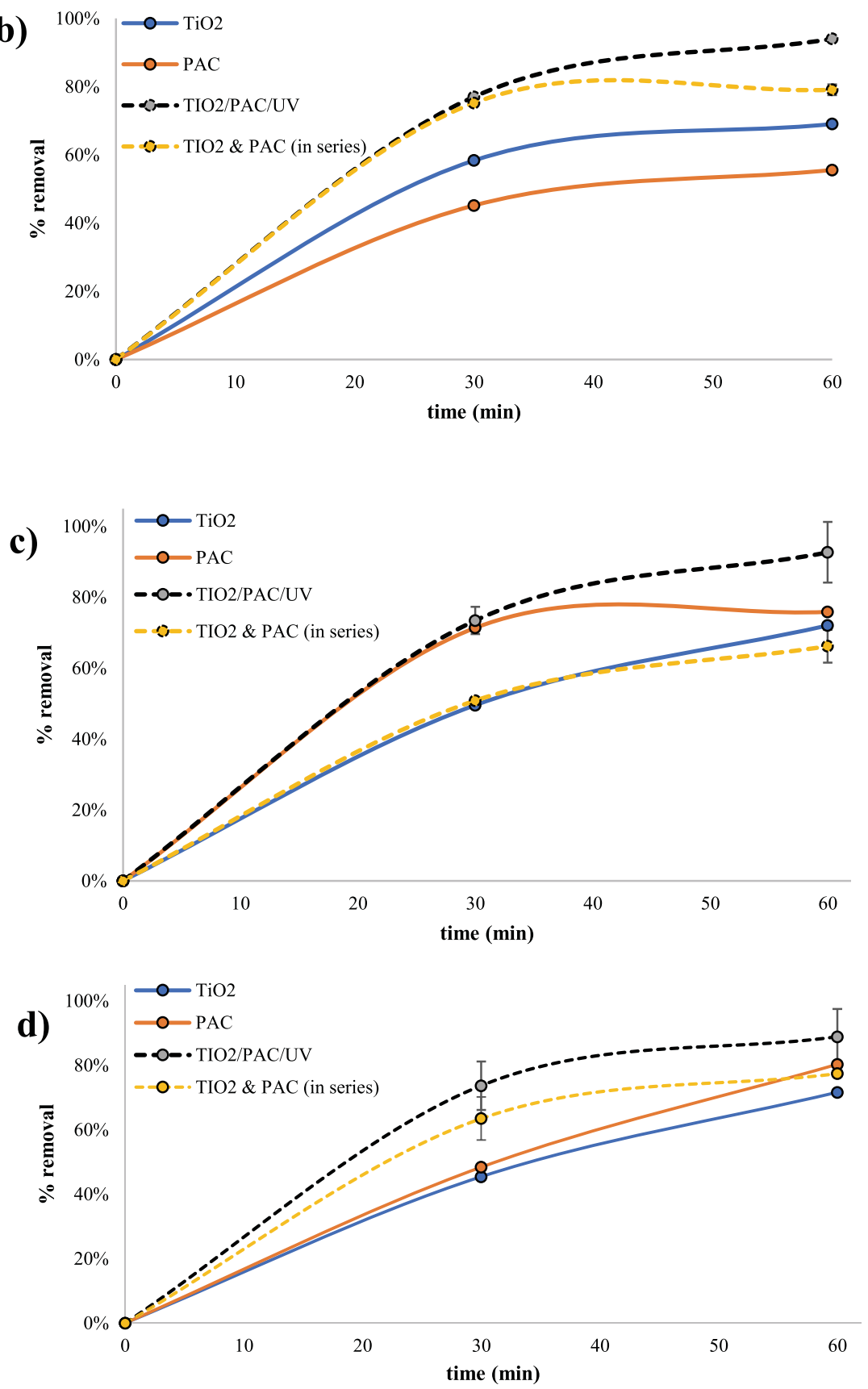
Table 2 Kinetic fitting parameters for amoxicillin, enrofloxacin, sulfadiazine, and trimethoprim

\begin{tabular}{|c|c|c|c|c|}
\hline Pseudo-second order & Amoxicillin & Enrofloxacin & Sulfadiazine & Trimethoprim \\
\hline$q_{\mathrm{e}}(\mathrm{mg} / \mathrm{g})$ & 133.7 & 158.5 & 152.05 & 134.8 \\
\hline$k_{2}(\mathrm{~g} / \mathrm{mg} \min )$ & $3.31 \times 10^{-3}$ & $7.76 \times 10^{-4}$ & $1.08 \times 10^{-3}$ & $1.61 \times 10^{-3}$ \\
\hline$R$ & 0.999 & 0.9992 & 0.9991 & 0.9984 \\
\hline Intraparticular diffusion & Amoxicillin & Enrofloxacin & Sulfadiazine & Trimethoprim \\
\hline$k\left(\mathrm{mg} / \mathrm{g} \min ^{1 / 2}\right)$ & 2.83 & 7.13 & 7.14 & 4.91 \\
\hline$I(\mathrm{mg} / \mathrm{g})$ & 103.6 & 77.0 & 75.8 & 81.9 \\
\hline$R$ & 0.9073 & 0.9622 & 0.8445 & 0.9023 \\
\hline Pseudo-first order & Amoxicillin & Enrofloxacin & Sulfadiazine & Trimethoprim \\
\hline$q_{\mathrm{e}}(\mathrm{mg} / \mathrm{g})$ & 21.2 & 88.1 & 60.3 & 22.1 \\
\hline$K_{1}(1 / \min )$ & 0.034 & 0.041 & 0.052 & 0.023 \\
\hline$R$ & 0.9301 & 0.9894 & 0.9726 & 0.55 \\
\hline
\end{tabular}

UV-vis treatment. The enhancement of photocatalytic degradation of pharmaceuticals by using $\mathrm{TiO} 2 / \mathrm{PAC}$ mixture is in accordance with the finding of other researchers who examined the immobilization of $\mathrm{TiO}_{2}$ on activated carbon for removal of different organic compounds (Asenjo et al., 2013). This fact suggests that the process improvement depends on the antibiotic family and chemical properties. Amoxicillin was the only of the four antibiotics that showed a significant synergy applying the $\mathrm{TiO}_{2} / \mathrm{PAC} / \mathrm{UV}$-vis treatment, reaching a $30 \%$ higher removal than the removal percentage obtained by applying $\mathrm{TiO}_{2}$ photocatalysis and PAC adsorption in sequential treatments. This fact could be explained by a combined adsorption and decomposition process under light and $\mathrm{OH}$ radicals, leading to a higher availability of unoccupied adsorption sites. Moreover, since carbonaceous material is well known as an effective adsorbent due to hydrophobic interactions, hydrogen-bounding interactions, and electrostatic and dispersion interactions (Awfa et al., 2018), the adsorption is enhanced by the structure of the amoxicillin degradation products (Trovó et al., 2011), capable of establishing $\pi-\pi$ interactions, as well as hydrogen bonds and electrostatic interactions (Moura et al., 2018; Peng et al., 2016). The antibiotic removal degree achieved by $\mathrm{TiO}_{2} / \mathrm{PAC} / \mathrm{UV}$-vis process in suspension in $30 \mathrm{~min}$ of treatment is significantly higher if it is compared to research works where other pharmaceuticals were treated by composite of AC impregnated with $\mathrm{TiO}_{2} / \mathrm{UV}$ vis (Gu et al., 2019; El Mouchtari et al., 2020). The results of amoxicillin removal are consistent with the trend reported in

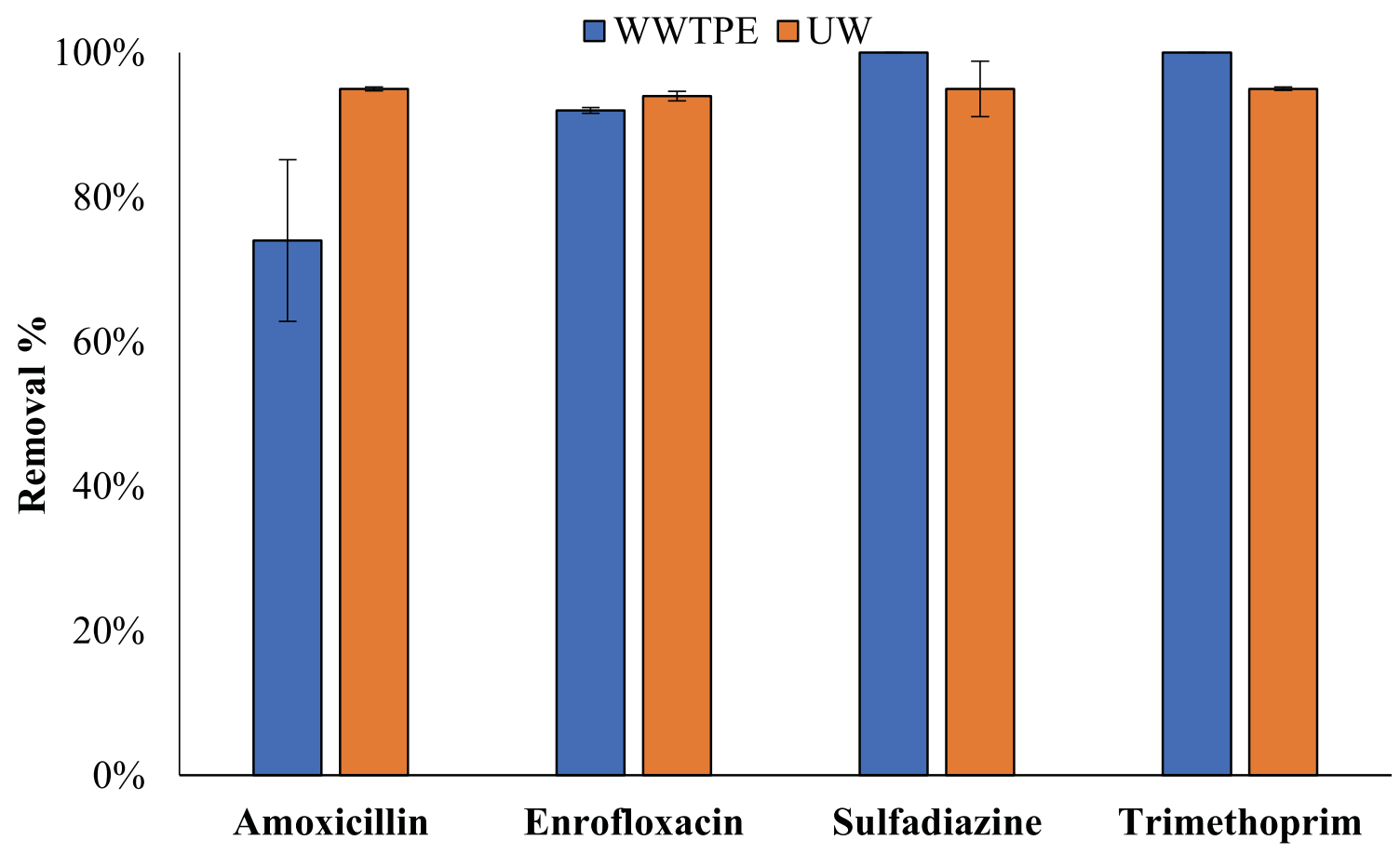

Fig. 4 Percentage of removal in WWTPE and Ultrapure water after $60 \mathrm{~min}$ of treatment of $\mathrm{PAC} / \mathrm{TiO}_{2} / \mathrm{UV}$-Vis 
Table 3 Influence of UV-vis radiation in the $\%$ removal of amoxicillin and enrofloxacin after among $60 \mathrm{~min}$ of TiO $2 / \mathrm{PAC} / \mathrm{UV}$-vis. $C_{0}=15 \mathrm{mg} / 1 \mathrm{Iv}=1$ $\mathrm{W} / 1,1 \mathrm{~g} / 1 \mathrm{TiO}_{2}, 0.1 \mathrm{~g} / 1 \mathrm{PAC}$

\begin{tabular}{|c|c|c|c|c|c|c|c|c|c|}
\hline \multicolumn{2}{|c|}{ Amoxicillin } & \multicolumn{3}{|c|}{$\%$ Removal } & \multicolumn{2}{|c|}{ Enrofloxacin } & \multicolumn{3}{|c|}{$\%$ Removal } \\
\hline \multicolumn{2}{|c|}{ Radiation/volume } & $1 \mathrm{~W} / 1$ & $2 \mathrm{~W} / 1$ & $3 \mathrm{~W} / 1$ & \multicolumn{2}{|c|}{ Radiation/volume } & $1 \mathrm{~W} / 1$ & $2 \mathrm{~W} / \mathrm{l}$ & $3 \mathrm{~W} / 1$ \\
\hline \multirow[t]{3}{*}{ Time } & $10 \mathrm{~min}$ & $81 \%$ & $81 \%$ & $78 \%$ & Time & $10 \mathrm{~min}$ & $62 \%$ & $68 \%$ & $73 \%$ \\
\hline & $30 \mathrm{~min}$ & $90 \%$ & $93 \%$ & $90 \%$ & & $30 \mathrm{~min}$ & $77 \%$ & $84 \%$ & $92 \%$ \\
\hline & $60 \mathrm{~min}$ & $95 \%$ & $94 \%$ & $95 \%$ & & $60 \mathrm{~min}$ & $94 \%$ & $97 \%$ & $98 \%$ \\
\hline
\end{tabular}

other studies focused on the removal of sulfamethazine $(\mathrm{Yu}$ et al., 2019) and methylene blue (Mills, 2012) with MOFs and metal oxides, while the rest of the selected antibiotics do not show the same behavior.

Regarding the antibiotics removal achieved by other advanced oxidation processes, the photo-Fenton treatment is reported to be more effective in Fenton-like processes. Furthermore, some authors suggested that the estimated costs of $\mathrm{TiO}_{2} / \mathrm{PAC}$ photocatalysis and photo-Fenton are similar (Gar Alalm et al., 2016). Comparing the operational conditions of both advanced oxidation processes, photo-Fenton process is reported known to be favored at acidic conditions (Zepp et al., 1992), which might induce to operational problems such as corrosion. Moreover, since traces of iron remained in the treated effluent, it might cause environmental problems; meanwhile, $\mathrm{TiO}_{2}$ is not harmful to the environment (Byrne et al., 2018).

\section{Kinetic study}

Regarding the kinetics, the experimental data fulfills follows pseudo-first order (Eq. 2), pseudo-second order (Eq. 3), and Weber-Morris intraparticular diffusion (Eq. 4) and as reported in the bibliography (Ensano et al., 2019; Yue et al., 2014; Ahmed \& Theydan, 2014). In Eq. 2, $k_{1}$ is the rate constant of the pseudo-first-order model (L/min). In Eq. $3, K_{2}$ is the rate constant of the pseudo-second-order model $(\mathrm{g} /(\mathrm{mg} \cdot \mathrm{min}))$. In Eq. $4, l$ is a parameter relating to the thickness of the boundary layer and $k$ is the intraparticle diffusion rate constant.

$\ln \left(q_{e}-q_{t}\right)=\ln q_{e}-k_{1} t$
$\frac{t}{q}=\frac{1}{K_{2} q_{e}^{2}}+\frac{1}{q_{e}} t$

$q=k t^{1 / 2}+l$

The $q(\mathrm{mg} / \mathrm{g})$ of every experiment was fitted to the pseudosecond order, Morrison-Weber intra-particle diffusion, and pseudo-first order models. Regardless of the tested antibiotic or the initial concentration, the kinetics of the adsorption process presented an overall better fitting to the pseudo-second order equation, ruling out intraparticle diffusion as a limiting step. Table 2 gathers the adsorption kinetics parameters for the fitting the equations to the data of the antibiotics. The suggested kinetics are consistent with the reported bibliography for enrofloxacin (Berges et al., 2020; Chowdhury et al., 2019), trimethoprim (Ngo et al., 2010), amoxicillin (Moussavi et al., 2013; Limousy et al., 2017), and sulfadiazine (Liu et al., 2017).

\section{Matrix influence}

The influence of matrix has been studied in the $\mathrm{TiO}_{2} / \mathrm{PAC} /$ $\mathrm{UV}$-vis treatment, comparing the performance of the treatment in ultrapure water (UW) and real-treated urban wastewater (WWTPE). Literature suggests that the removal percentage tends to decrease when the treatment is applied in real wastewaters rather than ultrapure water. This behavior has been reported by other authors, using treatments based on $\mathrm{TiO}_{2} /$ UV-vis oxidation (Cabrera-Reina et al., 2019) or PAC adsorption (Guillossou et al., 2020). The presence of suspended

Table 4 Influence of UV-vis radiation in the $\%$ removal of sulfadiazine and trimethoprim after among $60 \mathrm{~min}$ of TiO $/ \mathrm{PAC} / \mathrm{UV}$-vis. $C_{0}=15 \mathrm{mg} / \mathrm{Iv}=$ $1 \mathrm{~W} / 1,1 \mathrm{~g} / 1 \mathrm{TiO}_{2}, 0.1 \mathrm{~g} / 1 \mathrm{PAC}$

\begin{tabular}{|c|c|c|c|c|c|c|c|c|c|}
\hline \multicolumn{2}{|c|}{ Sulfadiazine } & \multicolumn{3}{|c|}{$\%$ Removal } & \multicolumn{2}{|c|}{ Trimethoprim } & \multicolumn{3}{|c|}{$\%$ Removal } \\
\hline \multicolumn{2}{|c|}{ Radiation/volume } & $1 \mathrm{~W} / 1$ & $2 \mathrm{~W} / 1$ & $3 \mathrm{~W} / 1$ & \multicolumn{2}{|c|}{ Radiation/volume } & $1 \mathrm{~W} / 1$ & $2 \mathrm{~W} / 1$ & $3 \mathrm{~W} / 1$ \\
\hline \multirow[t]{3}{*}{ Time } & $10 \mathrm{~min}$ & $37 \%$ & $51 \%$ & $68 \%$ & Time & $10 \mathrm{~min}$ & $63 \%$ & $58 \%$ & $69 \%$ \\
\hline & $30 \mathrm{~min}$ & $73 \%$ & $84 \%$ & $91 \%$ & & $30 \mathrm{~min}$ & $74 \%$ & $80 \%$ & $86 \%$ \\
\hline & $60 \mathrm{~min}$ & $93 \%$ & $95 \%$ & $97 \%$ & & $60 \mathrm{~min}$ & $89 \%$ & $89 \%$ & $90 \%$ \\
\hline
\end{tabular}


Fig. 5 Evolution of \% removal per gram of $\mathrm{TiO}_{2}+\mathrm{PAC}$ during 3 cycles of $60 \mathrm{~min}$ for each

antibiotic. a Enrofloxacin, b

sulfadiazine, $\mathbf{c}$ amoxicillin, $\mathbf{d}$

trimethoprim. $C_{0}=15 \mathrm{mg} / \mathrm{l} \mathrm{Iv}=1$

$\mathrm{W} / 1,1 \mathrm{~g} / 1 \mathrm{TiO}_{2}, 0.1 \mathrm{~g} / 1 \mathrm{PAC}$
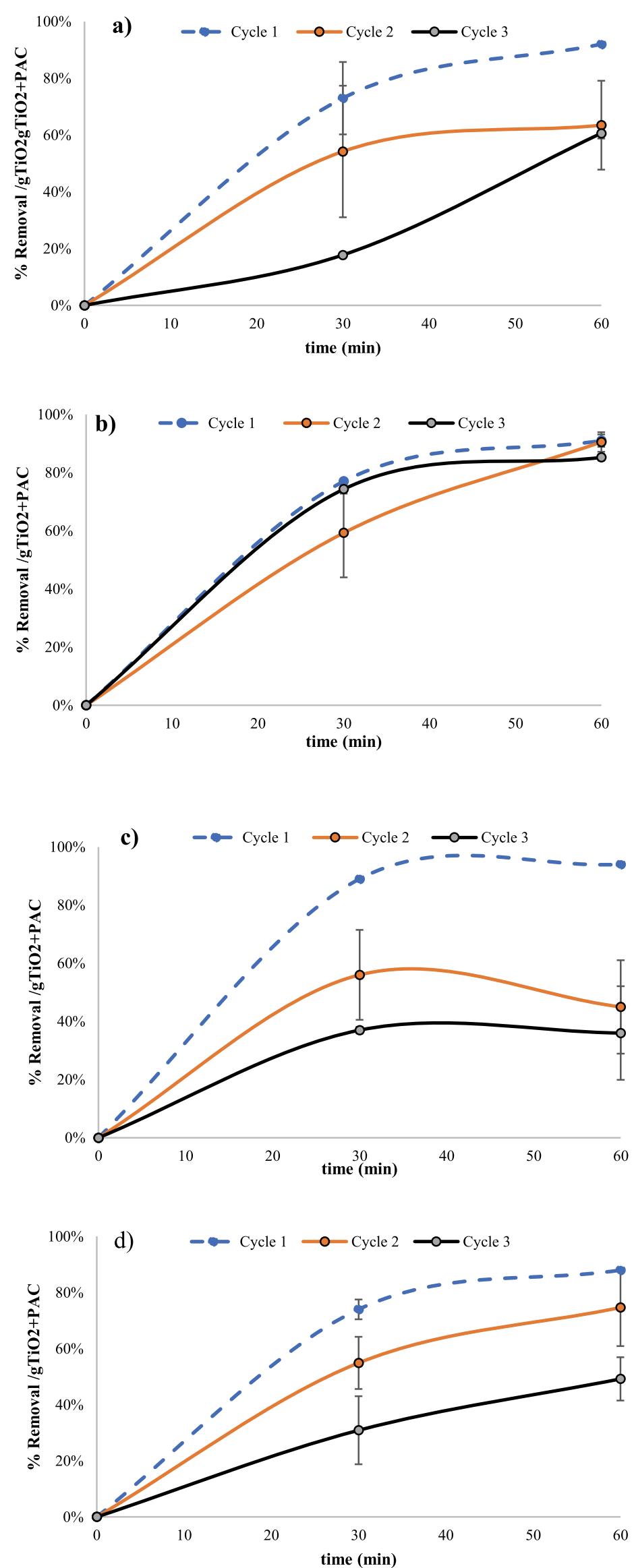

Springer 
Fig. 6 Reuse performance without regeneration (cycle 1, cycle 2 , and cycle 3 ) and applying UV-light regeneration (Cycle2 Reg and Cycle3 Reg). Evolution of sulfadiazine removal per gram of $\mathrm{TiO}_{2} / \mathrm{PAC} . C_{0}=15 \mathrm{mg} / \mathrm{l}$, Iv $=1$ $\mathrm{W} / 1,1 \mathrm{~g} / 1 \mathrm{TiO}_{2}, 0.1 \mathrm{~g} / \mathrm{PAC}$

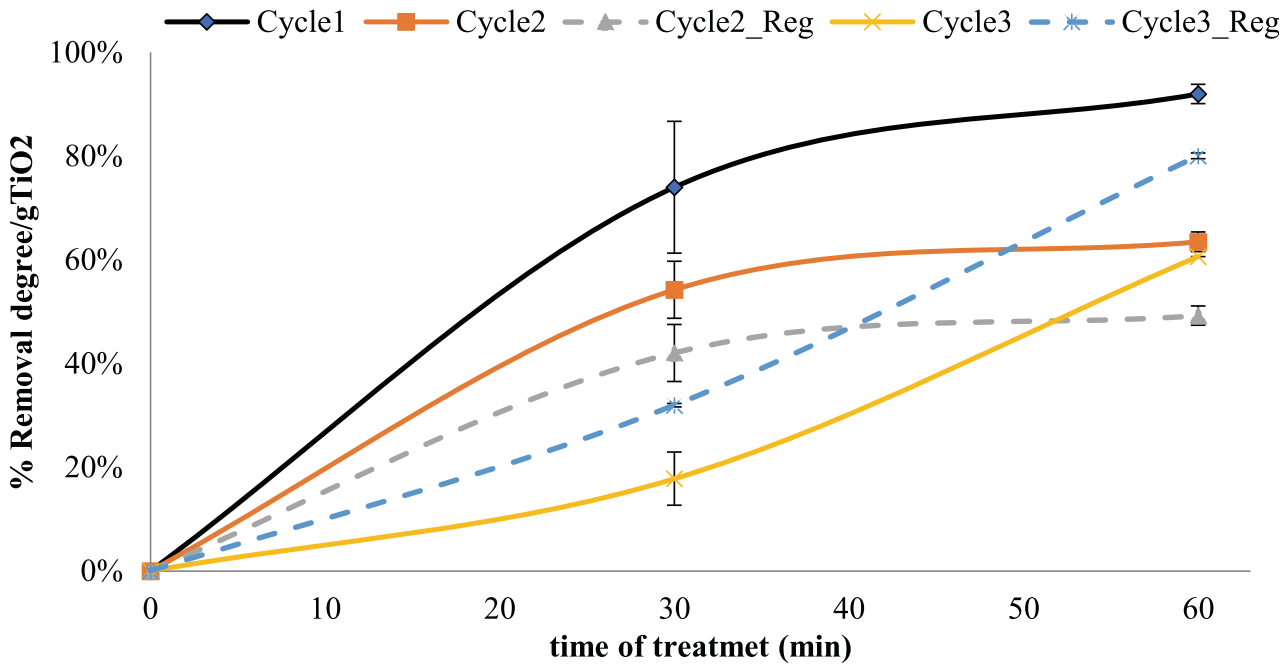

solids, organic matter, and other substances known as scavengers is known to lead to a reduction in the concentration of $\mathrm{OH}$-radicals in water, having also an effect on light propagation through the reactor, resulting in the aforementioned decrease of photocatalytic efficiency of the process $\mathrm{TiO} 2 / \mathrm{PAC} / \mathrm{UV}$-vis. Moreover, the presence of organic matter and suspension solids and other substances susceptible to be adsorbed causes a reduction of available adsorption sites in the $\mathrm{TiO} 2 / \mathrm{PAC}$ mixture (Wang et al., 2019). However, the results of antibiotics removal after $60 \mathrm{~min}$ of $\mathrm{TiO}_{2} / \mathrm{PAC} / \mathrm{UV}$-vis treatment in treated wastewater and ultrapure water (Fig. 4) show that the effect of water matrix is practically negligible. The $\mathrm{TiO} 2 / \mathrm{PAC} / \mathrm{UV}$-vis process reaches the complete removal of trimethoprim and sulfadiazine, in these operational conditions in both matrixes. By contrast, amoxicillin and enrofloxacin do not reach the total removal; more than $90 \%$ removal was achieved for both antibiotics in the studied matrixes. This trend might be attributed to the presence of inorganic species such as $\mathrm{H}_{2} \mathrm{O}_{2}, \mathrm{SO}_{3}{ }^{2-}$, and $\mathrm{BrO}_{3}{ }^{-}$present in wastewater. Literature suggest that these species can improve the photocatalytic remediation of pharmaceuticals by acting as electron scavengers, and consequently increasing the production of hydroxyl radicals and thus generating oxidizing species (Lee et al., 2017).

Some authors suggest that dissolved organic matter competes with some micro pollutants for the available active sites (Maletić et al., 2019; Al-Amin et al., 2016). By contrast, the results might suggest that antibiotics adsorption is enhanced by their structure, and the structure of degradation products capable of establishing electrostatic interactions (Moura et al., 2018; Peng et al., 2016). Finally, since OH· radicals are nonselective, the results suggest the concentration of $\mathrm{OH}$ radicals enough to remove simultaneously dissolved organic matter and target antibiotics.

\section{Study of radiation per unity of volume influence}

Antibiotic removal evolution during $60 \mathrm{~min}$ of $\mathrm{TiO}_{2} / \mathrm{PAC}-\mathrm{UV}$ treatment is shown in Tables 3 and 4. The results suggest an influence of the radiation intensity in the effectivity of the process. In a treatment time of $10 \mathrm{~min}$, an increase of the removal rate is observed when the applied radiation by volume unit increases as well. However, as treatment progresses, the influence of the radiation decreases. As a result, taking into account that at least an hour of treatment is needed in order to reach removal rates superior to $90 \%$, it would be convenient to work at the minor radiation $(1 \mathrm{~W} / 1)$, as it would constitute energy savings. Other authors have obtained similar results studying the influence of radiation in photocatalytic processes, such as the degradation of phenol (Chiou et al., 2008).

Independently from the studied antibiotic and the scheduled radiation, the antibiotic rate removal remains constant with treatment times superior to $30 \mathrm{~min}$. For these treatment times, a removal rate near to $100 \%$ is observed: up to $98 \%$ of initial enrofloxacin, $97 \%$ of sulfadiazine, $95 \%$ of amoxicillin, and a $90 \%$ of trimethoprim (Tables 2 and 3).

\section{Study of Ti02/PAC mixture reuse and regeneration}

Figure 5 shows the efficiency of the mixture of $\mathrm{TiO}_{2} / \mathrm{PAC}$ in the antibiotic removal process for each one of the three-reuse cycles. The highest antibiotic removal rate corresponds to the first cycle and the removal decreases with subsequent cycles as other authors have suggested (Moles et al., 2020; Wang et al., 2019), presenting the second cycle lesser removal rates than the first one and higher rates than the third cycle. This reduction could be explained by the clogging of the surface of PAC active sites by the antibiotics and its degradation products, causing a reduction on the pore size. This phenomenon allowed the adsorption of less antibiotic molecules in each cycle, with the subsequent reduction on the removal 
percentage (Wang et al., 2019). This reduction on the efficiency of removal is greater for the antibiotics which can be easier removed when they are treated exclusively with PAC rather than a treatment using only $\mathrm{TiO}_{2}$ (amoxicillin, sulfadiazine, and trimethoprim) supporting this theory.

Finally, catalyst regeneration is considered a key step to achieve a cheap, scalable, and environmentally friendly method to apply photocatalysis by means of $\mathrm{TiO}_{2} / \mathrm{PAC}$ mixture. The results of the regeneration experiment carried out with sulfadiazine and a radiation intensity of $1 \mathrm{~W} / 1$ are shown in Fig. 4. It can be observed that, while the second cycle (C2) presents less efficiency when the $\mathrm{TiO} 2 / \mathrm{PAC}$ mixture is regenerated (C2_Reg), the third cycle of the regeneration (C3_Reg) experiments is able to remove more antibiotics than its homologue for the reuse experiments (C3). The change in efficiency relative to the reuse experiments between cycles might be explained by the time of the regeneration stage. Each regeneration cycle consists of $2 \mathrm{~h}$ of treatment, insufficient for a complete regenerate the $\mathrm{TiO} 2 / \mathrm{PAC}$ mixture, and reach the initial performance, leading to smaller efficiencies (Andriantsiferana et al., 2014; Sharma \& Lee, 2017). However, in the (C3 Reg), $\mathrm{TiO}_{2} / \mathrm{PAC}$ mixture has been exposed to a total of $4 \mathrm{~h}$ of regeneration, and thereby, it gets higher capacities than its homologue without regeneration via UV-vis (C3) Fig 6.

\section{Conclusions}

The application of $\mathrm{TiO} 2 / \mathrm{PAC} / \mathrm{UV}$-vis in suspension is a promising process, because it reduces energy and chemical consumption. Consequently, this research work has studied the performance of the process, as well as operational conditions such as radiation per unity of volume and performance evolution after three cycles. Regarding the results of this study, the following conclusions can be drawn:

(1) The application of $\mathrm{TiO} 2 / \mathrm{PAC}$ mixture in suspension allows the removal of the target antibiotics in the range 90 $97 \%$ in 60 min of treatment

(2) Amoxicillin was the only of the four antibiotics that showed a significant synergy applying the $\mathrm{TiO}_{2} / \mathrm{PAC} /$ $\mathrm{UV}$-vis treatment, and this fact might be attributed to their structure capable of stablishing electrostatic interactions with the $\mathrm{TiO}_{2} / \mathrm{PAC}$ mixture.

(3) There is no influence of the water matrix (ultrapure water or treated wastewater) in $\mathrm{TIO}_{2} / \mathrm{PAC} / \mathrm{UV}-\mathrm{V}$ is process. Though dissolved organic matter of treated wastewater might decrease the performance of the process, the effluent of the WWTP also contains inorganic matter, which increases the concentration of oxidizing species resulting in a similar performance of the process in both matrixes.
(4) The regeneration of the $\mathrm{TiO} 2 / \mathrm{PAC}$ mixture is possible applying, at least, $4 \mathrm{~h}$ of exposure to $3 \mathrm{~W} / \mathrm{l}$ of $\mathrm{UV}$-vis light. By contrast, the reuse essays without regeneration showed that the aforementioned mixture tends to be deactivated gradually among various cycles, according to the results a $15 \%$ inferior removal of all antibiotics per cycle in average.

(5) FTIR and FESEM characterization of the material prove the formation of $\mathrm{TiO} 2$ nanoparticles in both the pores and the surface of PAC, thus confirming the possibility of establishing a synergy on the degradation of certain antibiotics.

Supplementary Information The online version contains supplementary material available at https://doi.org/10.1007/s11356-021-12542-4.

Acknowledgments We would like to acknowledge the assistance of the Servicio General de Apoyo a la Investigación-SAI, University of Zaragoza (Spain), and of the Instituto de Carboquímica-CSIC.

Authors' contributions Samuel Moles: writing and experimental procedure designed. Javier Berges: co-writing and experimental essays. Maria P. Ormad: experimental design. M. Jesús Nieto-Monge: experimental essays. Jairo Gomez: experimental design and result interpretation. Rosa Mosteo: coordination.

Funding This work was financed by the DGA_FSE Research Team "Water and Environmental Health" Ref: B43-20R in the framework of the project EFA 183/16/OUTBIOTICS, Program Interreg-POCTEFA 2014-2020, funded by FEDER.

Data availability Data sharing is not applicable to this article as not dataset were generated or analyzed during the study.

\section{Compliance with ethical standards}

Competing interests The authors declare that they have no competing interest.

Ethical approval Not applicable.

Consent to participate Not applicable.

\section{References}

Ahmed MJ, Theydan SK (2014) Fluoroquinolones antibiotics adsorption onto microporous activated carbon from lignocellulosic biomass by microwave pyrolysis. J Taiwan Inst Chem Eng 45(1):219-226

Al-Amin M, Chandra Dey S, Rashid TU, Ashaduzzaman M, Shamsuddin SM (2016) Solar assisted photocatalytic degradation of reactive azo dyes in presence of anatase titanium dioxide. Int J Latest Res Eng Technol (IJLRET) 2(March):14-21 Available from: www.ijlret.com

Andriantsiferana C, Mohamed EF, Delmas H (2014) Photocatalytic degradation of an azo-dye on $\mathrm{TiO} 2 /$ activated carbon composite material. Environ Technol (United Kingdom) 35(3):355-363

Asenjo NG, Santamaría R, Blanco C, Granda M, Álvarez P, Menéndez R (2013) Correct use of the Langmuir-Hinshelwood equation for proving the absence of a synergy effect in the photocatalytic degradation 
of phenol on a suspended mixture of titania and activated carbon. Carbon N Y 55:62-69

Aukidy M, Al Verlicchi P, Jelic A, Petrovic M, Barcelò D (2012) Science of the total environment monitoring release of pharmaceutical compounds : occurrence and environmental risk assessment of two WWTP ef fl uents and their receiving bodies in the Po Valley, Italy. Sci Total Environ 438:15-25. Available from. https://doi. org/10.1016/j.scitotenv.2012.08.061

Awfa D, Ateia M, Fujii M, Johnson MS, Yoshimura C (2018) Photodegradation of pharmaceuticals and personal care products in water treatment using carbonaceous- $\mathrm{TiO} 2$ composites: a critical review of recent literature. Water Res 142:26-45. Available from. https://doi.org/10.1016/j.watres.2018.05.036

Babić S, Ašperger D, Mutavdžić D, Horvat AJM, Kaštelan-Macan M (2006) Solid phase extraction and HPLC determination of veterinary pharmaceuticals in wastewater. Talanta. 70(4):732-738

Bahrudin NN, Nawi MA (2018) Immobilized titanium dioxide/powdered activated carbon system for the photocatalytic adsorptive removal of phenol. Korean J Chem Eng 35(7):1532-1541

Berges J, Moles S, Ormad MP, Mosteo R, Gómez J. (2020) Antibiotics removal from aquatic environments: adsorption of enrofloxacin, trimethoprim, sulfadiazine, and amoxicillin on vegetal powdered activated carbon. Environ Sci Pollut Res.

Biancullo F, Moreira NFF, Ribeiro AR, Manaia CM, Faria JL, Nunes OC, Castro-Silva SM, Silva AMT (2019) Heterogeneous photocatalysis using UVA-LEDs for the removal of antibiotics and antibiotic resistant bacteria from urban wastewater treatment plant effluents. Chem Eng J 367:304-313

Boy-Roura M, Mas-Pla J, Petrovic M, Gros M, Soler D, Brusi D, Menció A (2018) Towards the understanding of antibiotic occurrence and transport in groundwater: findings from the Baix Fluvià alluvial aquifer (NE Catalonia, Spain). Sci Total Environ 612:1387-1406

Byrne C, Subramanian G, Pillai SC (2018) Recent advances in photocatalysis for environmental applications. J Environ Chem Eng 6:3531-3555

Cabrera-Reina A, Martínez-Piernas AB, Bertakis Y, Xekoukoulotakis NP, Agüera A, Sánchez Pérez JA (2019) TiO2 photocatalysis under natural solar radiation for the degradation of the carbapenem antibiotics imipenem and meropenem in aqueous solutions at pilot plant scale. Water Res 166:115037

Cai Q, Hu J (2017) Decomposition of sulfamethoxazole and trimethoprim by continuous UVA/LED/TiO2 photocatalysis: decomposition pathways, residual antibacterial activity and toxicity. J Hazard Mater 323:527-536

Chiou CH, Wu CY, Juang RS (2008) Influence of operating parameters on photocatalytic degradation of phenol in $\mathrm{UV} / \mathrm{TiO} 2$ process. Chem Eng J 139(2):322-329

Chowdhury S, Sikder J, Mandal T, Halder G (2019) Comprehensive analysis on sorptive uptake of enrofloxacin by activated carbon derived from industrial paper sludge. Sci Total Environ 665:438-452

El Mouchtari EM, Daou C, Rafqah S, Najjar F, Anane H, Piram A et al (2020) TiO2 and activated carbon of Argania Spinosa tree nutshells composites for the adsorption photocatalysis removal of pharmaceuticals from aqueous solution. J Photochem Photobiol A Chem 388(July 2019):112183

Ensano BMB, de Luna MDG, Rivera KKP, Pingul-Ong SMB, Ong DC (2019) Optimization, isotherm, and kinetic studies of diclofenac removal from aqueous solutions by $\mathrm{Fe}-\mathrm{Mn}$ binary oxide adsorbents. Environ Sci Pollut Res 26:32407-32419

Gar Alalm M, Tawfik A, Ookawara S (2016) Enhancement of photocatalytic activity of TiO 2 by immobilization on activated carbon for degradation of pharmaceuticals. J Environ Chem Eng 4(2):19291937

García-Galán MJ, Garrido T, Fraile J, Ginebreda A, Díaz-Cruz MS, Barceló D (2010) Simultaneous occurrence of nitrates and sulfonamide antibiotics in two ground water bodies of Catalonia (Spain). J Hydrol 383(1-2):93-101

García-Gil A, Garrido Schneider E, Mejías M, Barceló D, Vázquez-Suñé E, Díaz-Cruz S (2018) Occurrence of pharmaceuticals and personal care products in the urban aquifer of Zaragoza (Spain) and its relationship with intensive shallow geothermal energy exploitation. J Hydrol 566(June):629-642

Golovko O, Kumar V, Fedorova G, Randak T, Grabic R (2014) Chemosphere Seasonal changes in antibiotics, antidepressants/ psychiatric drugs, antihistamines and lipid regulators in a wastewater treatment plant. Chemosphere 111:418-426. Available from. https://doi.org/10.1016/j.chemosphere.2014.03.132

Gu Y, Yperman J, Carleer R, D’Haen J, Maggen J, Vanderheyden S et al (2019) Adsorption and photocatalytic removal of Ibuprofen by activated carbon impregnated with $\mathrm{TiO} 2$ by $\mathrm{UV}-\mathrm{Vis}$ monitoring. Chemosphere 217:724-731. Available from:. https://doi.org/10. 1016/j.chemosphere.2018.11.068

Guillossou R, Le Roux J, Mailler R, Pereira-Derome CS, Varrault G, Bressy A et al (2020) Influence of dissolved organic matter on the removal of 12 organic micropollutants from wastewater effluent by powdered activated carbon adsorption. Water Res 172:115487

Herrmann JM, Matos J, Disdier J, Guillard C, Laine J, Malato S, Blanco J (1999) Solar photocatalytic degradation of 4-chlorophenol using the synergistic effect between titania and activated carbon in aqueous suspension. Catal Today 54(2-3):255-265

Jurado A, Walther M, Díaz-Cruz MS (2019) Occurrence, fate and environmental risk assessment of the organic microcontaminants included in the Watch Lists set by EU Decisions 2015/495 and 2018/840 in the groundwater of Spain. Sci Total Environ 663:285-296

Klein EY, Van Boeckel TP, Martinez EM, Pant S, Gandra S, Levin SA et al (2018) Global increase and geographic convergence in antibiotic consumption between 2000 and 2015. Proc Natl Acad Sci U S A 115(15):E3463-E3470

Kuehn BM (2007) Antibiotic-resistant "superbugs" may be transmitted from animals to humans. Med News Perspect Futur 298(18):21252126

Lee CM, Palaniandy P, Dahlan I (2017) Pharmaceutical residues in aquatic environment and water remediation by $\mathrm{TiO} 2$ heterogeneous photocatalysis: a review. Environ Earth Sci 76(17):611

León A, Reuquen P, Garín C, Segura R, Vargas P, Zapata P et al (2017) FTIR and raman characterization of $\mathrm{TiO} 2$ nanoparticles coated with polyethylene glycol as carrier for 2-methoxyestradiol. Appl Sci 7(1): $1-9$

Limousy L, Ghouma I, Ouederni A, Jeguirim M (2017) Amoxicillin removal from aqueous solution using activated carbon prepared by chemical activation of olive stone. Environ Sci Pollut Res 24(11): 9993-10004

Liu P, Wang Q, Zheng C, He C (2017) Sorption of sulfadiazine, norfloxacin, metronidazole, and tetracycline by granular activated carbon: kinetics, mechanisms, and isotherms. Water Air Soil Pollut 228(4): 129

Maletić M, Vukčević M, Kalijadis A, Janković-Častvan I, Dapčević A, Laušević Z, Laušević M (2019) Hydrothermal synthesis of TiO2/ carbon composites and their application for removal of organic pollutants. Arab J Chem 12(8):4388-4397

Matos J, Laine J, Herrmann JM (1998) Synergy effect in the photocatalytic degradation of phenol on a suspended mixture of titania and activated carbon. Appl Catal B Environ 18(3-4):281-291

Mceneff G, Barron L, Kelleher B, Paull B, Quinn B (2014) Science of the total environment: a year-long study of the spatial occurrence and relative distribution of pharmaceutical residues in sewage ef fl uent, receiving marine waters and marine bivalves. Sci Total Environ [Internet] 476-477:317-326. Available from. https://doi.org/10. 1016/j.scitotenv.2013.12.123 
Mills A (2012) An overview of the methylene blue ISO test for assessing the activities of photocatalytic films. Appl Catal B Environ 128: 144-149

Milosevic I, Jayaprakash A, Greenwood B, Van Driel B, Rtimi S, Bowen $P$ (2017) Synergistic effect of fluorinated and $n$ doped TiO2nanoparticles leading to different microstructure and enhanced photocatalytic bacterial inactivation. Nanomaterials 7(11):391

Mirzaei R, Yunesian M, Nasseri S, Gholami M, Jalilzadeh E, Shoeibi S et al (2017) An optimized SPE-LC-MS/MS method for antibiotics residue analysis in ground, surface and treated water samples by response surface methodology- central composite design. J Environ Health Sci Eng 15(1):1-16

Moles S, Valero P, Escuadra S, Mosteo R, Gómez J, Ormad MP. (2020) Performance comparison of commercial TiO2: separation and reuse for bacterial photo-inactivation and emerging pollutants photo-degradation. Environ Sci Pollut Res. (Who 2016).

Moura FCC, Rios RDF, Galvão BRL (2018) Emerging contaminants removal by granular activated carbon obtained from residual Macauba biomass. Environ Sci Pollut Res 25(26):26482-26492

Moussavi G, Alahabadi A, Yaghmaeian K, Eskandari M (2013) Preparation, characterization and adsorption potential of the $\mathrm{NH} 4 \mathrm{Cl}$-induced activated carbon for the removal of amoxicillin antibiotic from water. Chem Eng J 217:119-128

Ngo HH, Kim SH, Shon HK (2010) Adsorption characteristics of antibiotics trimethoprim on powdered and granular activated carbon. J Ind Eng Chem 16(3):344-349

Peng B, Chen L, Que C, Yang K, Deng F, Deng X et al (2016) Adsorption of antibiotics on graphene and biochar in aqueous solutions induced by $\pi-\pi$ interactions. Sci Rep 6(July):1-10

Qiu X, Miyauchi M, Sunada K, Minoshima M, Liu M, Lu Y, Li D, Shimodaira Y, Hosogi Y, Kuroda Y, Hashimoto K (2012) Hybrid $\mathrm{Cu} \times \mathrm{O} / \mathrm{TiO} 2$ nanocomposites as risk-reduction materials in indoor environments. ACS Nano 6(2):1609-1618

Rossmann J, Schubert S, Gurke R, Oertel R, Kirch W (2014) Simultaneous determination of most prescribed antibiotics in multiple urban wastewater by SPE-LC - MS / MS. J Chromatogr B 969: 162-170. Available from:. https://doi.org/10.1016/j.jchromb.2014. 08.008

Senta I, Terzic S, Ahel M (2013) Occurrence and fate of dissolved and particulate antimicrobials in municipal wastewater treatment. Water Res 47(2):705-714
Sharma A, Lee BK (2017) Growth of TiO2 nano-wall on activated carbon fibers for enhancing the photocatalytic oxidation of benzene in aqueous phase. Catal Today 287:113-121

Tamtam F, Mercier F, Le Bot B, Eurin J, Tuc Dinh Q, Clément M et al (2008) Occurrence and fate of antibiotics in the Seine River in various hydrological conditions. Sci Total Environ 393(1):84-95

Trovó AG, Pupo Nogueira RF, Agüera A, Fernandez-Alba AR, Malato S (2011) Degradation of the antibiotic amoxicillin by photo-Fenton process - chemical and toxicological assessment. Water Res 45(3): 1394-1402

Tuc Dinh Q, Alliot F, Moreau-Guigon E, Eurin J, Chevreuil M, Labadie P (2011) Measurement of trace levels of antibiotics in river water using on-line enrichment and triple-quadrupole LC-MS/MS. Talanta. 85(3):1238-1245

USEPA. (2007) Method 1694 : pharmaceuticals and personal care products in water, soil, sediment, and biosolids by HPLC/MS/MS. EPA Method (December):77.

Wagil M, Kumirska J, Stolte S, Puckowski A, Maszkowska J, Stepnowski P, Białk-Bielińska A (2014) Development of sensitive and reliable LC-MS/MS methods for the determination of three fluoroquinolones in water and fish tissue samples and preliminary environmental risk assessment of their presence in two rivers in northern Poland. Sci Total Environ 493:1006-1013

Wang N, Li X, Yang Y, Guo T, Zhuang X, Ji S, Zhang T, Shang Y, Zhou Z (2019) Enhanced photocatalytic degradation of sulfamethazine by Bi-doped TiO2 nano-composites supported by powdered activated carbon under visible light irradiation. Sep Purif Technol 211(100): 673-683

Yu J, Kiwi J, Wang T, Pulgarin C, Rtimi S (2019) Evidence for a dual mechanism in the $\mathrm{TiO} 2 / \mathrm{Cu}$ x O photocatalyst during the degradation of sulfamethazine under solar or visible light: Critical issues. $\mathrm{J}$ Photochem Photobiol A Chem 375(February):270-279

Yue Q, Sun Y, Gao B, Gao Y, Xu X, Li Q et al (2014) Adsorption and cosorption of ciprofloxacin and $\mathrm{Ni}(\mathrm{II})$ on activated carbonmechanism study. J Taiwan Inst Chem Eng 45(2):681-688

Zepp RG, Faust BC, Jürg H (1992) Hydroxyl Radical formation in aqueous reactions ( $\mathrm{pH} 3-8)$ of iron(II) with hydrogen peroxide: the photo-fenton reaction. Environ Sci Technol 26(2):313-319

Publisher's note Springer Nature remains neutral with regard to jurisdictional claims in published maps and institutional affiliations. 